\title{
Protein C and S Deficiency, Thrombophilia, and Hypofibrinolysis: Pathophysiologic Causes of Legg-Perthes Disease
}

\author{
CHARLES J. GLUECK, HELEN I. GLUECK, DAVID GREENFIELD, RICHARD FREIBERG, \\ ALFRED KAHN, TRACEY HAMER, DAVIS STROOP, AND TRENT TRACY \\ Cholesterol Center, Jewish Hospital [C.J.G., T.H., T.T.J: Departments of Orthopedics, Jewish [D.G., R.F.] and \\ Christ [A.K.] Hospitals; and Departments of Pathology and Laboratory Medicine, University of Cincinnati \\ College of Medicine [H.I.G., D.S.], Cincinnati, Ohio 45229
}

\begin{abstract}
In eight patients with Legg-Perthes disease, we assessed the etiologic roles of thrombophilia caused by protein $\mathbf{C}$ and protein $\mathbf{S}$ deficiency and hypofibrinolysis mediated by low levels of tissue plasminogen activator activity. We speculated that thrombosis or hypofibrinolysis were common causes of Legg-Perthes disease. Three of the eight patients had protein $C$ deficiency; they came from kindreds with previously undiagnosed protein $\mathrm{C}$ deficiency. In one of these three kindreds there were six protein Cdeficient family members (beyond the proband child), four of whom had thrombotic events as adults. One of the eight patients had protein $\mathbf{S}$ deficiency, as did his brother who had sustained mesenteric vein thrombosis at age 43. One of the eight patients who had normal proteins $\mathrm{C}, \mathrm{S}$, and antithrombin III had hypofibrinolysis, failing to elevate tissue plasminogen activator activity after $10 \mathrm{~min}$ of venous occlusion at $100 \mathrm{~mm} \mathrm{Hg}$. Plasminogen activator inhibitor, $\alpha_{2}$-antiplasmin, and fibrinogen values were normal in all eight patients. Beyond their Legg-Perthes disease, none of the eight patients had evidence for venous thrombosis. Of the eight patients, four had thrombophilia and one had hypofibrinolysis, disorders that we believe contributed to thrombotic venous occlusion of the femur with subsequent venous hypertension and bone death that characterize Legg-Perthes disease. (Pediatr Res 35: 383-388, 1994)
\end{abstract}

\section{Abbreviations}

PAI, plasminogen activator inhibitor

tPA, tissue plasminogen activator

tPA-Ag, tissue plasminogen activator antigen

tPA-Fx, tissue plasminogen activator activity

PAI-Fx, plasminogen activator inhibitor activity

PAI-Ag, plasminogen activator inhibitor antigen

We suspect that Legg-Perthes disease in children is a pediatric equivalent of idiopathic osteonecrosis of the femoral head in the adult (1-9). The cause of Perthes disease is unknown, and no uniform agreement exists regarding how best to treat the disease process (1-9). In dog models, when venous drainage of the surgical neck of the femur is obstructed, avascular necrosis resembling that of Legg-Perthes disease develops in the femoral head (8). It has been postulated that Legg-Perthes disease may

Received July 27, 1993; accepted November 22, 1993.

Correspondence and reprint requests: C. J. Glueck, M.D., Cholesterol Center, Jewish Hospital, 3200 Burnet Ave., Cincinnati, OH 45229.

Supported by Jewish Hospital Medical Research Council Grant \#733 from the Jewish Hospital Medical Research Council. be caused by intravascular thrombosis as a result of reduced fibrinolysis (9).

We have recently shown that hypofibrinolysis mediated by high levels of the major inhibitor of fibrinolysis, PAI, is a common major cause of idiopathic osteonecrosis $(10,11)$. Nine of 12 adults with idiopathic osteonecrosis had high levels of PAI with hypofibrinolysis $(10,11)$. The thrombogenic, atherogenic apolipoprotein, Lp(a), was elevated in 14 of 18 patients with secondary osteonecrosis, and protein C deficiency was present in 1 of the 18 patients, suggesting that thrombophilia and hypofibrinolysis also play major pathophysiologic roles in secondary osteonecrosis (11)

Estimates of the prevalence of heterozygous protein $\mathrm{C}$ deficiency vary widely from less than 1 in 200000 (12), to 1 in 16000 (13), to 1 in 200 to 300 (14). Even among patients with venous thromboembolic disease, low protein $\mathrm{C}$ levels ranging from 35 to $65 \%$ of the normal mean (presumed heterozygous protein $\mathrm{C}$ deficiency) are uncommon, being found in eight of 319 ( 1 of 40) (13) and two of 225 ( 1 of 113) (15) cases.

In studies of Dutch patients with heterozygous protein $\mathrm{C}$ deficiency $50 \%$ of heterozygotes and $10 \%$ of normal relatives had venous thromboembolism by age $45 \mathrm{y}$, and $50 \%$ of first thromboembolic episodes and $65 \%$ of recurrences were spontaneous, not preceded by surgery or pregnancy (16). The authors concluded that "... members of the family of a symptomatic heterozygote proband who are heterozygous for the mutation in the protein $C$ gene have an increased risk of venous thrombotic events compared with their normal family members." Homozygous protein $\mathrm{C}$ deficiency is rare and often fatal, seen in neonates with disseminated intravascular coagulation and purpura fulminans (16).

Heterozygous protein $S$ deficiency appears to be rare even among patients with proven acute deep vein thrombosis, seen in only $2.8 \%$ of 107 patients with thrombophilia (17).

Until our recent studies $(10,11)$, only six kindreds with familial hypofibrinolysis resulting from high PAI had been reported. Hence, heritable, primary protein $\mathrm{C}, \mathrm{S}$, and antithrombin III deficiencies (12-17) are rare, and familial hypofibrinolysis resulting from high PAI is rare $(10,11)$.

Considerable variability exists in estimates of the prevalence of Perthes disease, ranging from 1 in 1200 in Massachusetts (18), 1 in 1400 in British Columbia (19), 1 in 4750 in South Wales (20), and 1 in 12500 in the United Kingdom (21).

Assuming the prevalence of heterozygous protein $\mathrm{C}$ deficiency to be as high as 1 in 250 (14) and the prevalence of Perthes disease to be as high as 1 in $1300(18,19)$, then by chance alone the likelihood that a child would have Perthes disease and concurrent heterozygous protein $\mathrm{C}$ deficiency would, speculatively, be 1 in $325000(1 / 250 \times 1 / 1300)$. Within this frame of reference, and because hypofibrinolysis and thrombophilia play 
a major role in adult idiopathic and secondary osteonecrosis ( 10 , $11)$, our specific aim was to study the potentially etiologic roles of thrombophilia and hypofibrinolysis in eight patients who had Legg-Perthes disease.

\section{MATERIALS AND METHODS}

Patients. After identifying all cases with the diagnosis of LeggPerthes disease by review of patient records in two large clinical orthopedic practices, we obtained the names of 14 patients for potential follow-up. Of these 14 patients, selected solely by diagnosis codes, 5 no longer lived in Cincinnati, and 1 refused to participate; $8(57 \%)$ consented to have measures of fibrinolytic activity and quantitation of proteins $\mathrm{C}, \mathrm{S}$, and antithrombin III. No selection bias whatsoever existed. Because family and clinical histories were not obtained until the patients' first visit at our Cholesterol Center, we had no foreknowledge of other heritable disorders and no a priori postulates that could have affected patient selection in any way. All eight patients had typical age of presentation and characteristic clinical, radiologic, and physical findings of Legg-Perthes disease (1-9). Their osteonecrosis was not secondary to known causes such as corticosteroids, sickle cell disease, or hip fracture $(1,11)$. The work followed a research protocol approved by the Jewish Hospital Medical Research Council and was carried out with signed informed consent.

Measures of fibrinolytic activity, protein $C, S$, and antithrombin III. Basal and stimulated determinants of fibrinolysis and Ddimer were quantitated as previously reported $(11,22)$. After the patients fasted for 12-h, blood was obtained between $0800 \mathrm{~h}$ and $0900 \mathrm{~h}$ in seated patients to minimize the influence of time of day on regulators of basal and stimulated fibrinolytic activity (11). In seven of the eight probands, while they remained seated and after measurement of basal fibrinolytic regulators and Ddimer, stimulated fibrinolysis was measured after a standard stimulus $(10,11), 10 \mathrm{~min}$ of venous occlusion at $100 \mathrm{~mm} \mathrm{Hg}$ with a blood pressure cuff. Although we obtained measures of fibrinogen, plasminogen, and $\alpha_{2}$-antiplasmin before and after venous occlusion (in addition to tPA, PAI, and D-dimer), we did not display the postocclusion values for fibrinogen, plasminogen, and $\alpha_{2}$-antiplasmin because they are primarily affected by hemoconcentration and are not released from the endothelium in response to increased vascular transmural pressure.

tPA, the major fibrinolytic activity stimulator, was measured in two forms, tPA-Ag by ELISA (Imubind total tPA, American Diagnostica, Greenwich, CT), and tPA-Fx by a chromogenic technique [Biopool Spectrolyse (fibrin), American Diagnostica] $(11,22)$.

PAI-Fx, a major inhibitor of fibrinolysis (10, 11, 22-24), was measured with synthetic substrates [Biopool Spectrolyse (pL), American Diagnostica] $(11,22)$. This assay measures only the functionally active PAI. PAI-Ag was quantitated with $\mathrm{MAb}$ and ELISA (Imubind PAI-1, American Diagnostica) $(11,22)$. PAI$\mathrm{Ag}$ measures total antigen, i.e. both latent (bound to tPA) plus active PAI (free).

Additional measures of fibrinolytic regulators included $\alpha_{2}-$ antiplasmin (a fibrinolytic inhibitor) (S-2251, KabiVitrum, Franklin, $\mathrm{OH}$ ), plasminogen (Spectrozyme PL, American Diagnostica), and fibrinogen (Dade Thrombin, Baxter Healthcare Corp., Miami, FL) $(11,22)$.

D-dimers, split products from cross-linked fibrin, a measure of in vivo fibrinolysis $(11,22)$, were determined by ELISA (Dimertest, American Diagnostica) with MAb against D-dimer.

Protein C was measured by ELISA (Imubind Protein C, StripWell, American Diagnostica).

Protein S and antithrombin III were measured respectively by Rellplate S, American Diagnostica, and Dade Antithrombin III chromogenic assay (Baxter Healthcare Corp) $(25,26)$. Free protein $S$ was determined immunologically (25). In the proband with familial protein $S$ deficiency, a functional assay for protein $\mathrm{S}$ was also used (27) (Diagnostica Stago). C4B binding protein was also determined with an immunologic method (28) (American Bio Products, Parsippany, NJ).

Measurements of lipids, lipoprotein cholesterols, and apolipoproteins. Fasting lipids and lipoprotein cholesterols were quantitated in our Lipid Research Clinic's standardized laboratory by enzymatic methods (29-31), with calculation of LDL cholesterol when the triglyceride value was less than $400 \mathrm{mg} / \mathrm{dL}$. Serum apolipoproteins $\mathrm{A} 1$ and $\mathrm{B}$ were measured by rate-nephelometry (32). Lp(a) was measured by enzyme immunoassay with a Terumo-macra $\mathrm{Lp}$ (a) sequential monoclonal-polyclonal sandwich method (33).

\section{RESULTS}

Probands. As summarized in Table 1, we studied eight patients, including the following: six children and two young adults, seven males and one female, seven white and one black. The two young adults had Legg-Perthes disease at ages 8 y (patient 3) and 6 y (patient 8). We also studied all available first-degree relatives. All eight patients had typical age of disease onset and characteristic clinical, radiologic, and physical findings of Legg-Perthes disease (1-9, 34).

Although two of the eight patients (patients 3 and 8, Table 1) were studied decades after their clinical presentation, from our experience with hereditary thrombophilia and hypofibrinolysis in adults with idiopathic osteonecrosis $(10,11)$ and from the literature on protein $C$ and $S$ deficiency $(12-17,27,28)$, heritable hypofibrinolytic and thrombophilic defects are persistent from childhood, not transient.

Unexpectedly, and heretofore not previously reported (1-9, 34), four of the eight patients with Perthes had low LDL cholesterol values (patients $1,5,7$, and 8; Table 1). Of these four patients with hypobetalipoproteinemia, patient 8 had familial protein $\mathrm{S}$ deficiency, patient 7 had protein $\mathrm{C}$ deficiency, and patient 5 could not initiate fibrinolysis (Table 1). Of the three probands with protein $C$ deficiency (probands 2, 6, and 7; Table 1), proband 7 had familial hypobetalipoproteinemia (35) with very low total and LDL cholesterol and apo B; he also had Stickler's syndrome $(36,37)$, a pleiomorphic, dominantly transmitted trait that includes retinal detachment, degenerative arthritis, and, occasionally, cleft palate.

Proband 3 had moderately elevated total and LDL cholesterol, and proband 6 had elevated Lp(a) (Table 1).

Measures of basal and stimulated determinants of fibrinolysis, D-dimer, and proteins $C, S$, and antithrombin III. Overall, four of the eight probands had thrombophilic diseases [three with protein $C$ deficiency (probands 2, 6, and 7) and one with protein $\mathrm{S}$ deficiency (proband 8; Table 1]. One of the eight probands had hypofibrinolysis (proband 5).

Three of the probands (probands 2, 6, and 7) had previously undiagnosed low levels of protein $C$; their protein $S$ and antithrombin III levels were normal (Table 1). Beyond their LeggPerthes disease, these three probands with protein $C$ deficiency had no personal history of thrombophlebitis or venous thrombosis.

Family studies in kindred 2 (Fig. 1, Table 2) revealed that the Legg-Perthes proband's mother, maternal grandfather, uncle, aunt, sister, and female first cousin all had protein $C$ deficiency. All four adult family members with protein $C$ deficiency had experienced venous thrombosis, pulmonary emboli, or both; none had Legg-Perthes disease or osteonecrosis $(10,11)$ (Fig. 1). The proband's maternal grandfather $(I-1$, Fig. 1) was on coumadin when sampled because of recurrent thrombosis, which further depressed his low protein $\mathrm{C}$ levels. The only thrombotic event in generation III was in the pediatric proband with LeggPerthes disease $(I I I-3)$, presumably affecting the venous drainage of the femur (Fig. 1).

In addition to familial, three-generation, autosomal dominant, protein $C$ deficiency in kindred 2, there was also familial (10), three-generation, autosomal dominantly transmitted high (top 
Table 1. Fibrinolytic, thrombogenic, and lipid characteristics of eight probands with Legg-Perthes disease

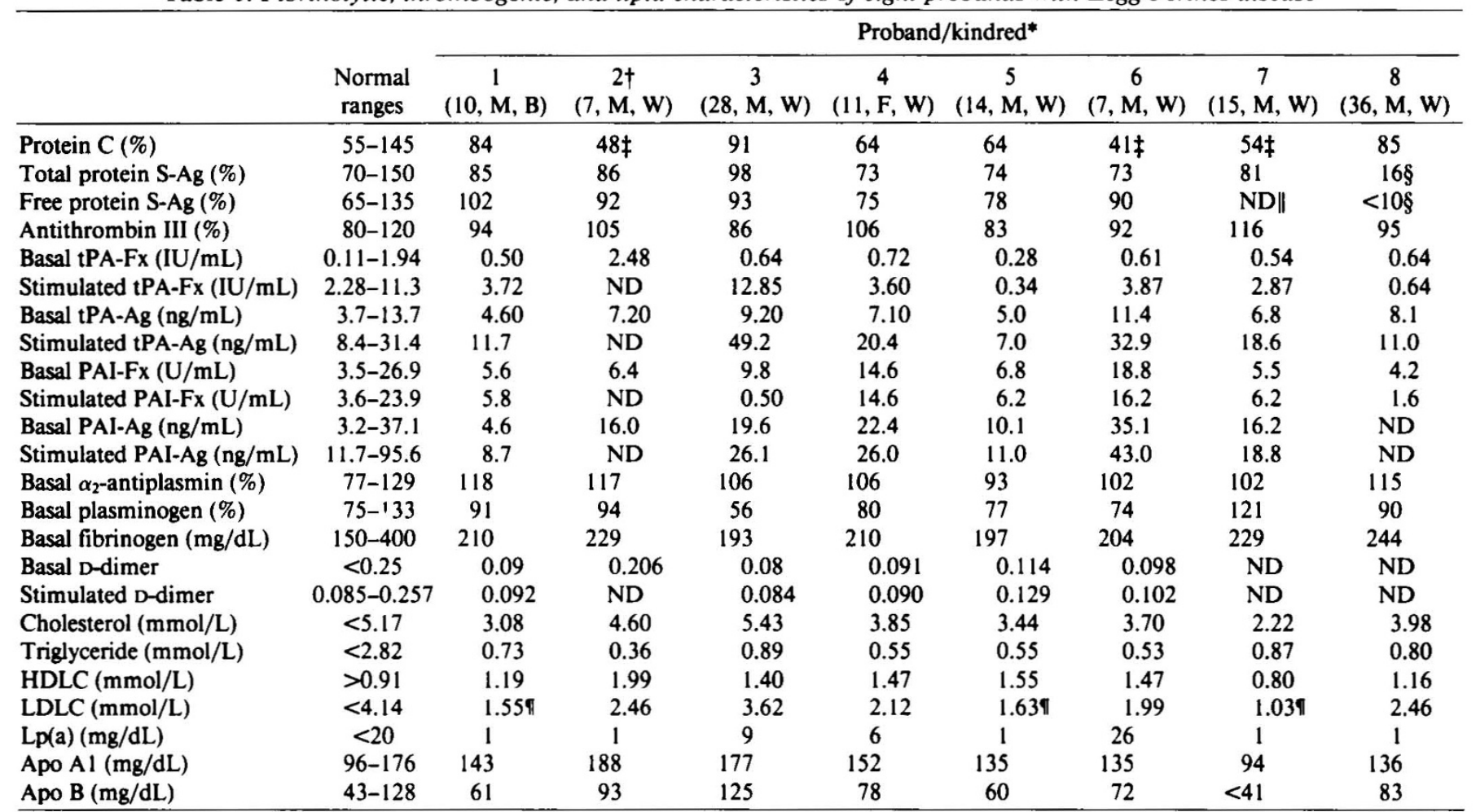

* Numbers and letters listed after proband/kindred number reflect the following: age (in years); sex ( $\mathrm{M}=$ male, $\mathrm{F}=$ female), and race ( $\mathrm{B}=\mathrm{black}$, $\mathbf{W}=$ white).

† Protein $\mathrm{C}$ data for kindred 2 displayed in Figure 1.

$¥$ Protein C deficiency.

$\S$ Protein S deficiency.

II ND, not done.

I LDL cholesterol <10th percentile (48).

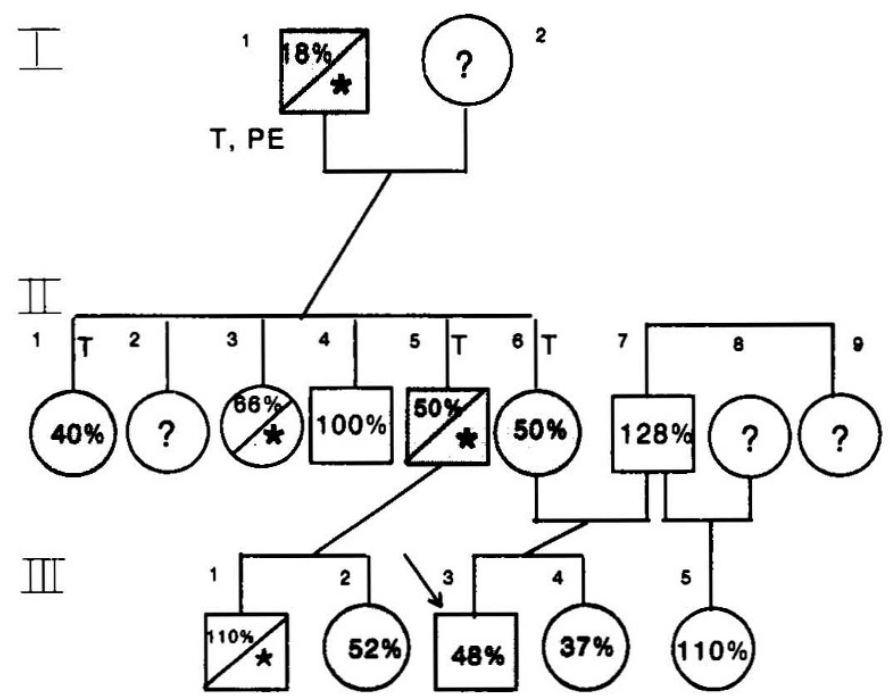

Fig. 1. Kindred 2. Three generations with familial protein $\mathrm{C}$ deficiency and with familial high PAI (10). The pediatric proband $(\rightarrow)$ with Legg-Perthes disease and protein C deficiency is III-3. Shaded symbols, Protein $C$ deficiency; $T$, thrombosis or thrombophlebitis; $P E$, pulmonary embolus; *, high PAI-Fx and/or high PAI-Ag. Protein C levels are displayed as $\%$ of normal. Normal range, $55-145 \%$. decile) PAI-Fx, PAI-Ag, or both (Table 2, Fig. 1). High PAI (Fx, $\mathrm{Ag}$, or both) and low tPA-Fx appeared to segregate independently of protein $\mathrm{C}$ deficiency (Table 2, Fig. 1). PAI-Ag and PAI-Fx, the major inhibitors of fibrinolysis $(10,11)$, were high in the proband's grandfather $(I-I)$, aunt $(I I-3)$, uncle $(I I-5)$, and male first cousin (III-I) (Table 2, Fig. 1). Inability to activate fibrinolysis (10) (to normally increase tPA in response to venous occlusion) accompanied high PAI in the proband's aunt (II-3), in his male first cousin $(I I I-1)$, and, unaccompanied by high PAI, was found in his female first cousin (III-2) (Table 2).

In kindred 6 , where the proband was protein $\mathrm{C}$ deficient (Table 1 ), his 9 -yr-old brother had normal protein $\mathrm{C}(78 \%)$, as did his 33 -yr-old mother (69\%). The proband's father was long separated from the family, and his whereabouts and health history were unknown. There was no history of thrombosis, thrombophlebitis, or Legg-Perthes disease in the proband's brother, mother, or maternal side of the family.

In kindred 7, where the proband was protein $\mathrm{C}$ deficient (Table 1), protein $C$ levels were normal in the mother $(93 \%)$, father (105\%), and sister (100\%). The mother and sister, like the proband, had familial hypobetalipoproteinemia with LDL cholesterol levels of 1.63 and $1.63 \mathrm{mmol} / \mathrm{L}$ respectively, and Stickler's syndrome. Beyond the proband's Legg-Perthes disease, there was no family history of thrombosis, thrombophlebitis, or osteonecrosis.

In kindred 8, beyond Legg-Perthes disease at age 6, the protein S-deficient proband had no history of thrombophlebitis or venous thrombosis despite major soft-tissue trauma from a recent severe automobile accident and from playing amateur soccer. In addition to the proband's very low levels of total protein $\mathrm{S}-\mathrm{Ag}$ (16\%; normal, 70-150\%), and very low free protein $\mathrm{S}-\mathrm{Ag}(<10 \%$; 
Table 2. Measurements of basal and stimulated fibrinolysis, lipids, and $L P(a)$ in kindred 2 with familial protein C deficiency*

\begin{tabular}{|c|c|c|c|c|c|c|c|c|c|c|c|c|}
\hline $\begin{array}{l}\text { Kindred } \\
\text { position }\end{array}$ & Age & Sex & $\begin{array}{c}\text { Basal } \\
\text { PAI-Ag } \\
(\mathrm{ng} / \mathrm{mL})\end{array}$ & $\begin{array}{c}\text { Basal } \\
\text { PAI-Fx } \\
(\mathrm{U} / \mathrm{mL})\end{array}$ & $\begin{array}{l}\text { Stimu- } \\
\text { lated } \\
\text { PAI-Fx } \\
\text { (U/mL) }\end{array}$ & $\begin{array}{c}\text { Basal } \\
\text { tPA-Fx } \\
(\mathrm{IU} / \mathrm{mL})\end{array}$ & $\begin{array}{c}\text { Stimulated } \\
\text { tPA-Fx } \\
(\mathrm{IU} / \mathrm{mL})\end{array}$ & $\begin{array}{c}\mathrm{TC} \\
(\mathrm{mmol} / \mathrm{L})\end{array}$ & $\begin{array}{c}\text { TG } \\
(\mathrm{mmol} / \mathrm{L})\end{array}$ & $\begin{array}{c}\text { HDLC } \\
(\mathrm{mmol} / \mathrm{L})\end{array}$ & $\begin{array}{c}\text { LDLC } \\
(\mathrm{mmol} / \mathrm{L})\end{array}$ & $\begin{array}{c}\mathrm{Lp}(\mathrm{a}) \\
(\mathrm{mg} / \mathrm{dL})\end{array}$ \\
\hline $\begin{array}{l}\text { Normal range } \\
\text { Kindred position }\end{array}$ & & & $3.2-37.1$ & $3.5-26.9$ & $3.6-23.9$ & $0.11-1.94$ & $2.28-11.28$ & $<5.17$ & $<2.82$ & $>0.91$ & $<4.14$ & $<20$ \\
\hline $\begin{array}{l}\mathrm{I}-1 \\
\mathrm{I}-2 \ddagger\end{array}$ & $\begin{array}{l}65 \\
68\end{array}$ & $\begin{array}{l}\mathbf{M} \\
\mathbf{F}\end{array}$ & $53.8 \dagger$ & 11.0 & 10.9 & 0.38 & 3.16 & 6.10 & 2.01 & 1.27 & 3.90 & 53 \\
\hline $\begin{array}{l}\text { II-1 } \\
\text { II-2‡ }\end{array}$ & $\begin{array}{l}36 \\
38\end{array}$ & $\begin{array}{l}\mathbf{F} \\
\mathbf{F}\end{array}$ & 6.7 & 5.4 & 2.8 & 0.98 & 6.52 & 5.59 & 1.76 & 1.50 & 3.28 & 1 \\
\hline II-3 & 42 & $\mathbf{F}$ & $109.6 \dagger$ & $53.8 \dagger$ & $63.0 \dagger$ & $0.07 \S$ & $2.16 \S$ & 5.69 & 0.98 & 1.55 & 3.70 & 1 \\
\hline II-4 & 40 & $\mathbf{M}$ & 21.2 & 8.2 & 9.6 & 0.60 & 2.42 & 5.28 & 1.39 & 1.40 & 3.23 & 1 \\
\hline II-5 & 46 & $\mathbf{M}$ & $69.8 \dagger$ & $47.7+$ & $61.6+$ & 0.23 & 3.46 & 8.46 & 1.46 & 1.86 & 5.92 & 1 \\
\hline II-6 & 33 & $F$ & 23.0 & 10.0 & 10.2 & 0.51 & 3.03 & 4.55 & .56 & 1.32 & 2.97 & 45 \\
\hline II-7 & 47 & $\mathbf{M}$ & 19.8 & 8.2 & 9.8 & 0.46 & 3.21 & 6.18 & 1.58 & 1.19 & 4.27 & 1 \\
\hline III-8‡ & 46 & $\mathrm{~F}$ & & & & & & & & & & \\
\hline II-9 & 49 & $F$ & 24.9 & 17.0 & 14.4 & 0.42 & 4.77 & 5.74 & 2.64 & 1.14 & 3.39 & 64 \\
\hline III-1 & 21 & $\mathbf{M}$ & $53.3+$ & $36.5 \dagger$ & $40.7 \dagger$ & 0.17 & $1.52 \S$ & 6.00 & 1.31 & 1.58 & 3.83 & 17 \\
\hline III-2 & 19 & $\mathrm{~F}$ & 10.8 & 5.8 & 8.4 & 0.50 & $1.04 \S$ & 5.97 & 2.70 & 1.76 & 2.97 & 17 \\
\hline III-3\| & 7 & $\mathbf{M}$ & 16.0 & 6.4 & NDq & 2.48 & ND & 4.60 & 0.36 & 1.99 & 2.46 & 1 \\
\hline III-4 & 13 & $F$ & 15.9 & 8.2 & ND & 0.60 & ND & 3.98 & 0.38 & 1.42 & 2.38 & 1 \\
\hline III-5 & 28 & $\mathrm{~F}$ & 7.2 & 6.8 & 6.6 & 0.97 & 5.01 & 4.22 & 1.16 & 1.47 & 2.20 & 1 \\
\hline
\end{tabular}

* Protein C levels (\% of normal) are displayed in Figure 1.

$\dagger$ High (top decile) PAI.

¥ Unavailable for blood sampling.

$\S$ Low (bottom decile) tPA-Fx.

|| Proband with Legg-Perthes disease.

I ND, not done.

normal, $65-135 \%)$, functional protein $S$ was very low $(<12.5 \%$; normal, $62-138 \%)$, as was the C4B binding protein (73\%; normal, 85-135\%; Table 1). As may occur in familial protein $S$ deficiency, the proband in kindred 8 failed to activate fibrinolysis (Table 1). His protein S-deficient brother had recurrent thromboses since age $19 \mathrm{y}$, and, despite long-term coumadin therapy, had sustained mesenteric vein thrombosis at age $43 \mathrm{y}$.

In proband 5 , after $10 \mathrm{~min}$ of venous occlusion, no activation of fibrinolysis occurred despite normal PAI-Fx, PAI-Ag, Lp(a), and normal proteins $\mathrm{C}, \mathrm{S}$, and antithrombin III (Table 1). We do not yet understand why this proband could not initiate fibrinolysis. Family members were unavailable for study. The proband had no thrombotic events beyond Legg-Perthes disease. There was no family history of thrombosis, thrombophlebitis, or osteonecrosis.

All eight probands had normal basal PAI-Fx and normal basal $\alpha_{2}$-antiplasmin and fibrinogen (Table 1).

Basal plasminogen was inexplicably low in proband 3 (Table 1). Basal D-dimer levels were normal in the six probands where they were measured (Table 1).

Postocclusion blood could not be obtained in proband 2; postocclusion, activated tPA-Fx was normal in five of the remaining seven probands, being low in proband 5 and in proband 8 , as above (Table 1 ).

\section{DISCUSSION}

In adults, we have recently shown that very high PAI with inability to activate fibrinolysis is a common cause of idiopathic osteonecrosis, whereas high $\mathrm{Lp}(\mathrm{a})$ or protein $\mathrm{C}$ deficiency may play an etiologic role in secondary osteonecrosis $(10,11)$. When we turned our attention to Legg-Perthes disease $(1-9,18-21,34)$, we postulated that we might again find high PAI with consequent inability to activate fibrinolysis $(10,11)$. However, in the current study, only one child could not initiate fibrinolysis, and he unexpectedly had normal PAI-Ag, PAI-Fx, and $\mathrm{Lp}(\mathrm{a})$, as well as normal proteins $\mathrm{C}, \mathrm{S}$, and antithrombin III. We do not yet know why he was unable to initiate fibrinolysis.

Of the eight patients with Legg-Perthes disease, four $(50 \%)$ had thrombophilic disorders $(12-17,27,28,38-44)$, three had primary thrombophilia with previously undiagnosed deficiency of protein $\mathbf{C}$, and one had familial protein S deficiency. Protein C and protein $\mathrm{S}$ deficiency, transmitted as autosomal dominant disorders $(38,40)$, are rare both in free-living, unselected population groups (12-14) and among cohorts selected because of thrombosis or thrombophlebitis, where they account for only a small percentage (usually $<5 \%$ altogether) of cases $(17,38-44)$. Hence, our finding that $50 \%$ of probands with Legg-Perthes also had protein $\mathbf{C}$ or $\mathbf{S}$ deficiency is exceptionally higher than would be suggested by chance (1 in 325000$)$ and implies causality, particularly because our probands with Perthes were sampled solely on the basis of their orthopedic diagnoses, their current residence in the Cincinnati area, and their willingness to participate in the study.

Given the remarkably low estimated likelihood ( 1 in 325000 ) that unselected children would have protein $\mathrm{C}$ or $\mathrm{S}$ deficiency and concurrent Legg-Perthes disease, a prospective study of children without symptoms of heterozygous for protein C deficiency to determine how many would have Legg-Perthes disease develop would be expensive and impractical. It would first require population screening of healthy children to identify those [1 in 250 (14) to 1 in 16000 (13)] with protein C deficiency, with subsequent follow-up through the end of skeletal maturation.

In one of the three kindreds where the proband had protein $C$ deficiency, there was three-generation vertical and horizontal transmission of low protein $C$ accompanied by thrombophlebitis and pulmonary emboli in protein C-deficient adults, characteristic of autosomal dominantly transmitted protein $\mathrm{C}$ deficiency $(16,38-44)$. All four protein C-deficient adults had thrombotic events but not osteonecrosis. Legg-Perthes disease apparently represented the thrombotic event in the pediatric proband. Unexpectedly, this kindred also had three-generation vertical and 
horizontal transmission of high PAI-Fx and/or high PAI-Ag, another dominantly transmitted trait that causes hypofibrinolysis and idiopathic osteonecrosis in adults $(10,11)$. The high PAI appeared to segregate independently of protein $\mathrm{C}$ deficiency. We have not found any reports of familial protein C-deficient kindreds who also had concurrent familial hypofibrinolysis (mediated by high PAI) $(10,11)$.

In two kindreds identified by a protein $\mathrm{C}$-deficient pediatric proband, familial protein $\mathrm{C}$ deficiency could not be demonstrated. In one of these two kindreds, the proband's father, the likely protein $\mathrm{C}$-deficient carrier, was unavailable. In the second kindred, both parents and a sibling unexpectedly (14-16) had normal protein $\mathrm{C}$.

In the kindred with protein S deficiency, the proband's Sdeficient brother had sustained mesenteric venous thrombosis and, characteristically $(17,27,28,38,40)$, began to have thrombotic events at age $19 \mathrm{y}$.

Presumably, thrombophilia associated with deficient protein $\mathrm{C}$ and $\mathrm{S}$ in childhood, in a fashion similar to hypofibrinolysis mediated by high PAI and/or by high $L p(a)$ in adults $(10,11)$, leads to venous thrombi in the femur with subsequent obstruction of bone venous drainage, venous hypertension, osteonecrosis, and Legg-Perthes disease $(8,9)$. We do not know what factors in protein $\mathrm{C}$ - and $\mathrm{S}$-deficient families cause some affected family members to have Legg-Perthes disease and some to have other sites for thrombosis (thrombophlebitis, for example).

The finding of protein $\mathrm{C}$ or $\mathrm{S}$ deficiency as common pathophysiologic causes of Legg-Perthes disease should open avenues to family diagnosis and to therapy. Children with Legg-Perthes syndrome should be systematically evaluated for protein $C$ and $\mathrm{S}$ deficiency and hypofibrinolysis. If thrombophilic, hypofibrinolytic disorders are found, all family members should be screened $(16,38)$.

In one kindred, protein $\mathrm{C}$ deficiency and familial hypobetalipoproteinemia (35) were both present in the proband. It is possible that the gene defects for apo $\mathrm{B}$ [responsible for familial hypobetalipoproteinemia (45-47)] and protein C (45) are linked on chromosome 2, an area deserving of further study. Protein $\mathrm{C}$ deficiency is transmitted as an autosomal dominant trait, with the gene located on chromosome 2 (q13-14) (45). Familial hypobetalipoproteinemia is transmitted as an autosomal dominant trait, with the apo B gene also located on chromosome 2 $(45-47)$. No published data exist suggesting that low total or LDL cholesterol could affect protein C levels or vice versa, and we postulate that the association of protein $\mathrm{C}$ deficiency and familial hypobetalipoproteinemia is genetic.

\section{REFERENCES}

1. Mankin JH 1992 Nontraumatic necrosis of bone (osteonecrosis). N Engl J Med 326:1473-1479

2. Ura Y, Hara T, Mori Y. Matsuo M, Fujioka Y, Kuno T, Okue A, Miyazaki S 1992 Development of Perthes' disease in a 3-year-old boy with idiopathic thrombocytopenic purpura and antiphospholipid antibodies. Pediatr Hematol Oncol 9:77-80

3. Meehan PL, Angel D, Nelson JM 1992 The Scottish Rite abduction orthosis for the treatment of Legg-Perthes disease. A radiographic analysis. J Bone Joint Surg [Am] 74:2-12

4. Martinez AG, Weinstein SL. Dietz. FR 1992 The weight-bearing abduction brace for the treatment of Legg-Perthes disease. J Bone Joint Surg [Am] $74: 12-21$

5. Kiepurska A 1992 Late results of treatment in Perthes' disease by a functional method. Clin Orthop 272:76-81

6. Kruse RW, Guille JT, Bowen JR 1991 Shelf arthroplasty in patients who have Legg-Calve-Perthes disease. A study of long-term results. J Bone Joint Surg [Am] 73:1338-1347

7. Norlin R, Hammerby S. Tkaczuk H 1991 The natural history of Perthes' disease. Int Orthop 15:13-16

8. Liu SL, Ho TC 1991 The role of venous hypertension in the pathogenesis of Legg-Perthes disease. A clinical and experimental study. J Bone Joint Surg [Am] 73:194-200

9. Gregosiewicz A, Okonski M, Stoecka D, Kandzierski G, Szponar M 1989
Ischemia of the femoral head in Perthe's disease: is the cause intra- or extravascular. J Pediatr Orthop 9:160-162

10. Glueck CJ, Glueck HI, Mieczkowski L, Tracy T, Speirs J, Stroop D 1993 Familial high plasminogen activator inhibitor with hypofibrinolysis, a new pathophysiologic cause of osteonecrosis? Thromb Haemost 69:460-465

11. Glueck CJ, Freiberg R, Glueck HI, Henderson C, Welch M, Tracy T, Stroop D, Hamer T, Sosa F, Levy M 1994 Hypofibrinolysis: a common major cause of osteonecrosis. Am J Hematol 45:156-166

12. McKee PA 1985 Disorders of blood coagulation. In: Wyngaarden JB, Smith LB (eds) Cecil, Textbook of Medicine. WB Saunders Co, Philadelphia, pp 1040-1058

13. Broekmans AW, van Der Linden IK, Veltkamp JJ, Bertina RM 1983 Prevalence of isolated protein $\mathrm{C}$ deficiency in patients with venous thrombotic disease and in the population. Thromb Haemost 50:350

14. Miletich J, Sherman L, Broze G 1987 Absence of thrombosis in subjects with heterozygous protein C deficiency. N Engl J Med 317:991-996

15. Pabinger-Fasching I, Bertina RM, Lechner K. Niessner H, Korninger C 1983 Protein $\mathrm{C}$ deficiency in two Austrian families. Thromb Haemost 50:810 813

16. Allaart CF, Poort S, Rosendaal FR, Reitsma PH, Bertina RM, Briet E. 1993 Increased risk of venous thrombosis in carriers of hereditary protein $\mathrm{C}$ deficiency defect. Lancet 341:134-138

17. Ben-Tal O, Zivelin A. Seligsohn U 1989 The relative frequency of hereditary thrombic disorders among 107 patients with thrombophilia in Israel. Thromb Haemost 61:50-54

18. Molloy MK, MacMahon B 1967 Birth weight and Legg-Perthes disease. J Bone Joint Surg 49A:498-506

19. Gray IM, Lowry RB, Renwick DHG 1972 Incidence and genetics of Legg Perthes disease (osteochondritis deformans) in British Columbia: evidence of polygenic determination. J Med Genet 9:197-202

20. Harper PS, Brotherton BJ, Cochlin D 1976 Genetic risks in Perthes disease Clin Genet 10:178-182

21. Barker DJP, Dixon E, Taylor JF 1978 Perthes' disease of the hip in three regions of England. J Bone Joint Surg 60B:478-480

22. Glueck CJ, Glueck HI, Tracy T, Speirs J, McCray C, Stroop D 1993 Relationships between lipoprotein(a), lipids, apolipoproteins, basal and stimulated fibrinolytic regulators, and D-dimer. Metabolism 42:236-246

23. Jorgenson M. Bonnevie-Nielsen V 1987 Increased concentration of fast-acting plasminogen activator in plasma associated with familial venous thrombosis. Br J Haematol 65:175-180

24. Patrassi GM, Sartori MT, Saggiorato G, Boeri G, Girolami A 1992 Familial thrombophilia associated with high levels of plasminogen activator inhibitor. Fibrinolysis 6:99-105

25. Laurell CB 1966 Quantitative estimation of proteins by electrophoresis in agarose gel containing antibodies. Anal Biochem 15:45-52

26. Harpel PC, Rosenberg RD 1976 Alpha 2-macroglobulin and antithrombinheparin cofactor: modulators of hemostatic and inflammatory reactions. In Spaet TH (ed) Progress in Hemostasis and Thrombosis. Vol 3. New York, Grune and Stratton, pp 145-189

27. Wolf M, Boyer-Neumann C, Leroy-Matheron C, Martinoli JI, Contant G, Amiral J, Meyer D. Larrieu MJ 1991 Functional assay of protein S in 70 patients with congenital and acquired disorders. Blood Coag Fibrinolysis 2:705-712

28. Bertina RM 1985 Hereditary protein S deficiency. Hemostasis 15:241-246

29. Allain C, Poon LS, Chan CSG, Richmond W, Fu PC 1974 Enzymatic determination of total serum cholesterol. Clin Chem 20:470-475

30. McGowan MW, Artiss JD, Strandbergh DR, Zak B 1983 A peroxidase-coupled method for the colorimetric determination of serum triglycerides. Clin Chem 29:538-543

31. Assman G, Schriewer H, Schmitz G, Hagele EO 1983 Quantification of high density lipoprotein cholesterol by precipitation with phosphotungstic acid/ $\mathrm{MgCl}_{2}$. Clin Chem 29:2026-2030

32. Glueck CJ, McCray C, Speirs J 1991 Measurement of serum Apo Al and Apo B: comparison of immunoturbidimetric and rate nephelometric techniques. Clin Chim Acta 197:123-132

33. Glueck CJ, McCray C, Stroop D, Tracy T, Speirs J 1992 Measurement of Lp(a): comparison of Terumo and Imubind methods. Clin Res 40:414A(abstr)

34. Bowen JR 1988 Legg-Calve'-Perthes disease. In: Dee R, Mango E, Hurst LC, Aprin H, Kaplan A (eds) Principles of Orthopaedic Practice. McGraw-Hil Book Co, New York, pp 1110-1128

35. Glueck CJ, Gartside PS, Mellies MJ, Steiner PM 1977 Familial hypobetalipoproteinemia: studies in 13 kindreds. Trans Assoc Am Physicians 90:184203

36. Stickler GB, Belav PG, Farrell FJ, Jones JD, Pugh JD, Steinberg AG, Ward LE 1965 Hereditary progressive arthro-ophthalmopathy. Mayo Clinic Proc 40:435-455 
37. Spallone A 1987 Stickler's syndrome: a study of 12 families. Br J Opthal 71:504-509

38. Pabinger I, Brucker S, Kyrle PA, Schneider B, Korninger HC, Neissner H, Lechner K 1992 Hereditary deficiency of antithrombin III, protein C, and protein S: prevalence in patients with a history of venous thrombosis and criteria for rational patient screening. Blood Coagul Fibrinolysis 3:547-558

39. Al-Momen AK, Gader AM, Shamena AR, Daif AK, Ajarim D 1991 Significant elevation of protein $C$ and protein $S$ levels in thrombotic disorders by low dose danazol. Blood Coagul Fibrinolysis 2:495-499

40. Tabernero MD, Tomas JF, Alberca I, Orfao A, Lopez Borrasca A, Vicente V 1991 Incidence and clinical characteristics of hereditary disorders associated with venous thrombosis. Am J Hematol 36:249-254

41. Heijboer H, Brandjes DP, Buller HR, Sturk A, Ten Cate JW 1990 Deficiencies of coagulation-inhibiting and fibrinolytic proteins in outpatients with deepvein thrombosis. N Engl J Med 323:1512-1516

42. Grimaudo V, Bachmann F, Hauert J, Christe MA, Kruithof EK 1992 Hypofibrinolysis in patients with a history of idiopathic deep vein thrombosis and/or pulmonary embolism. Thromb Haemost 67:397-401
43. Petaja J, Rasi V, Myullyia G, Vahtera E, Hallman H 1989 Familial hypofibrinolysis and venous thrombosis. Br J Haematol 71:393-398

44. Harper PL, Luddington RJ, Daly M, Bruce D, Williamson D, Edgar PF, Perry DJ, Carrell RW 1991 The incidence of dysfunctional antithrombin variants: four cases in 210 patients with thromboembolic disease. $\mathrm{Br} \mathbf{J}$ Haematol 77:360-364

45. McKusick VA 1990 Mendelian Inheritance in Man: Catalogs of Autosomal Dominant, Autosomal Recessive, and X-linked Phenotypes, 9th Ed. Johns Hopkins Press, Baltimore

46. Infante R, Pessah M 1992 Familial abeta and hypobeta lipoproteinemia. In: Stein $\mathrm{O}$, Stein S, Eisenberg Y (eds) Atherosclerosis IX. R and L Creative Communications, Tel Aviv, pp 189-193

47. Pessah M, Buecler I, Loux N, Navarro J, Guillerd X, Dulal O, Lequex J, Junien C, Infante R 1993 Genetic exclusion of apo B gene in recessive abetalipoproteinemia. Biochem Biophys Res Commun 190:97-103

48. National Institutes of Health 1980 The Lipid Research Clinics Population Studies Data Book. Vol I. The Prevalence Study. NIH Publication 80-1527, U.S. Government Printing Office, Washington, D.C. 